Published in final edited form as:

Semin Cancer Biol. 2008 June ; 18(3): 164-170.

\title{
The Neuroendocrine Impact of Chronic Stress on Cancer
}

\author{
Premal H. Thaker ${ }^{1}$ and Anil K. Sood 2,3 \\ 1 Division of Gynecologic Oncology, Department of Obstetrics and Gynecology, Washington University \\ School of Medicine, 4911 Barnes Jewish Medical Center, Campus Box 8064, St. Louis, MO 63110
}

2 Department of Gynecologic Oncology, U.T. M.D. Anderson Cancer Center, 1155 Herman Pressler, Unit 1362, Houston, TX 77030

3 Department of Cancer Biology, U.T. M.D. Anderson Cancer Center, 1515 Holcombe Boulevard, Unit 173, Houston, TX 77030

\begin{abstract}
Over the past 25 years, epidemiological and clinical studies have linked psychological factors such as stress, chronic depression, and lack of social support to the incidence and progression of cancer $[1,2]$. Although the mechanisms underlying these observations are not completely understood, recent molecular and animal studies have begun to identify specific signaling pathways that could explain the impact of neuroendocrine effects on tumor growth and metastasis. This review will highlight the importance of known clinical, molecular, and cellular processes with regard to the neuroendocrine stress effects on tumor biology and discuss possible behavioral and pharmacological interventions to ameliorate these effects and ultimately improve cancer outcomes.
\end{abstract}

\section{Keywords}

angiogenesis; carcinoma; stress; neuroendocrine

\section{Introduction}

The impact of psychosocial factors on the development of cancer has been a longstanding hypothesis. Around 200 A.D., Galen, the ancient Greek physician, recorded that women with "melancholic" disposition were more susceptible to breast cancer than "sanguine" women [3]. In 1936 Hans Selye defined stress physiologically as the state in which the autonomic nervous system (ANS) and the hypothalamic-pituitary-adrenal axis (HPA) are co-activated [4]. Today stress is considered a complex process encompassing environmental and psychosocial factors that initiates a cascade of information-processing pathways in both the peripheral and central nervous systems [5,6]. Then, the fight-or-flight stress responses in the ANS or the defeat/withdrawal responses in the HPA are created resulting in catecholamine secretion (norepinephrine and epinephrine) from the sympathetic neurons and adrenal medulla and cortisol from the adrenal cortex [7,8]. Although activation of these pathways in acute stress is necessary for adaptive processes and survival, in chronic stress these pathways have negative

Address correspondence and requests to: Anil K. Sood, Professor, Departments of Gynecologic Oncology and Cancer Biology, U.T. M.D. Anderson Cancer Center, 1155 Herman Pressler Unit 1362, P.O. Box 301439, Houston, Texas 77230-1439. Phone: (713) 745-5266; Fax: (713) 792-7586: Email: asood@mdanderson.org.

Publisher's Disclaimer: This is a PDF file of an unedited manuscript that has been accepted for publication. As a service to our customers we are providing this early version of the manuscript. The manuscript will undergo copyediting, typesetting, and review of the resulting proof before it is published in its final citable form. Please note that during the production process errors may be discovered which could affect the content, and all legal disclaimers that apply to the journal pertain. 
physiological effects due to the prolonged exposure to catecholamines and glucocorticoids [9].

Thus far, the majority of research on the deleterious effects of stress has focused on the neuroendocrine regulation of the immune response. These effects are thought to be mediated in part by the sympathetic nervous system, the HPA axis, and a variety of other hormones and peptides [8,10-13]. In both animal and human studies, chronic stress has been shown to decrease cellular immune parameters, such as natural killer (NK) cell cytotoxicity and T-cell responses to mitogen stimulation [14-16]. However, the uncertain role of the immune system in regulating solid tumor growth led us to consider an alternative hypothesis: stress mediators from the sympathetic nervous system might directly regulate the growth and metastatic potential of tumor cells, independent of the effects on the immune system [17]. Recently, there is growing evidence confirming that alterations in neuroendocrine dynamics due to chronic stress can cause alterations in tumor pathogenesis [17-21]. In this review, we will focus on these biological pathways that may be affected by stress mediators.

\section{Neuroendocrine Influences on Biological Pathways of Cancer}

In humans, tumorigenesis is a multistep process that requires many rate-limiting steps including both genetic and epigenetic processes in order for a normal cell to transform into a malignant cell [22]. According to Hanahan and Weinberg, there are six essential acquired alterations in cell physiology that dictate malignant growth: 1) self-sufficiency in growth signals, 2) insensitivity to anti-growth signals, 3) evasion of apoptosis, 4) limitless replicative potential, 5) sustained angiogenesis, and 6) tissue invasion and metastasis [22]. After establishment of the primary cancer, metastasis can occur if a series of sequential, interrelated steps including proliferation/angiogenesis, invasion, embolism/circulation, transport, arrest in organs, adherence to vessel wall, and extravasation occur [23] \{Table 1\}. Metastasis is a result of crosstalk between different cell types within the tumor, tumor stroma, and microenvironment [24]. Recently, research is beginning to delineate the role of neuropeptides and neurotransmitters, which are increased in certain biobehavioral states, on the multistep process of cancer development and metastasis.

\section{Proliferation and growth of primary tumor and metastases}

Tumor proliferation relies on nutrient and oxygen diffusion. Currently, there are limited data regarding the effects of stress hormones on proliferation. The majority of the data show that catecholamines suppress proliferation of normal cells such as keratinocytes, thereby leading to impaired wound healing in the context of stress [25]. Depending on the tumor type, adrenergic receptor, and stress-related hormones, the effects of stress-related hormones on tumor cell proliferation can be either stimulatory or inhibitory. For example, in a breast cancer model, activation of beta-adrenergic receptors (ADRB) has been shown to accelerate tumor growth $[19,20,26]$. In contrast, Carie and Sebti have demonstrated that ADRB2 agonist pirbuterol causes human tumor regression in MDA-MB-231 breast cancer in vivo by blocking the Raf-1/Mek-1/Erk1/2 pathway. However, the authors acknowledge that this approach is limited to human cancers that not only express $A D R B 2$, but also that stimulation of this receptor results in the blockade of the Raf-1/Mek-1/Erk 1/2 pathway [27]. In addition to the stimulation by catecholamines on ADRB2, carcinogens like nicotine may interact with ADRB2 and the downstream protein kinase C/Erk1/2/cyclooxygenase 2 pathway to lead to cell proliferation of gastric cancer cells [28]. Additionally, the cyclic AMP responsive element-binding (CREB) protein is an important transcription factor that is activated by many signal transduction pathways in response to external stimuli such as stress hormones [29,30]. Several studies have demonstrated a role for the CREB family of proteins in tumor cell proliferation, migration, angiogenesis, and inhibition of apoptosis [29-31]. Further studies will be instructive in 
delineating the specific signaling pathways responsible for ADRB2 mediated effects on tumor cell proliferation.

In other models, catecholamines inhibit tumor cell proliferation that may be mediated by the $\alpha$-adrenergic receptor or the dopamine transporter. Treating melanoma cells with the $\alpha_{1}$ adrenergic agonist phenylephrine led to a dose-dependent decrease in proliferation that could be reversed by using prazosin, $\alpha_{1}$-adrenergic antagonist [32]. Pifl and colleagues found that norepinephrine treatment caused neuroblastoma cells expressing the dopamine transporter to enter into the G0/G1 phase thereby blocking proliferation [33].

The role of glucocorticoid hormones on cancer cell proliferation has been examined; however, there are limited data with regard to the effects of glucocorticoids along with neuroendocrine hormones. Zhao and associates described that cortisol, the main circulating glucocorticoid and cortisone the main metabolite, stimulated growth of prostate cancer cells in the absence of androgens and increased the secretion of prostate specific antigen. The androgen receptor was mutated and acted as a high-affinity cortisol/cortisone receptor [34]. Simon and colleagues examined the effects of several steroid hormones on mammary carcinoma cells in vitro and found that biologically relevant concentrations of glucocorticoids enhanced proliferation by almost two-fold [35].

\section{Adhesion}

The ability of a tumor cell to ultimately invade and metastasize to outlying tissues relies on adhesion to the extracellular matrix within tissues [36]. The extracellular matrix is dynamic and consists of type I and IV collagens, laminins, heparin, sulfate proteoglycan, fibronectin, and other noncollagenous glycoproteins [37]. Integrins are cell surface receptors that interact with the extracellular matrix and mediate intracellular signals. There is emerging evidence that stress hormones may modulate tumor-stroma interactions. For example, Enserink and associates have shown that the $\beta$-agonist isoproterenol promotes ovarian cancer cell spreading and adhesions via integrins through the Epac (exchange factor directly activated by cAMP)Rap1 pathway $[38,39]$. Ultimately, stress hormones may promote cell-matrix attachment of cancer cells. This mechanism would be especially relevant in ovarian cancer where the primary tumor sheds cancer cells that are then able to implant diffusely onto peritoneal surfaces and organs.

\section{Migration and invasion}

The migration of tumor cells is a prerequisite for invasion into the host stroma, blood vessels, and lymphatics and ultimately the development of metastasis, which accounts for approximately $90 \%$ of cancer mortality [40]. There is growing evidence that stress hormones affect tumor cell motility and invasion. Drell and associates showed that multiple neurotransmitters such as substance $\mathrm{P}$, dopamine, and norepinephrine had a stimulatory effect on the migration of breast cancer cells, but only norepinephrine had a chemotactic effect on breast cancer cells [41]. Similarly, other groups have demonstrated that norepinephrine was a potent inducer of colon cancer and prostate cancer cell migration, which could be inhibited by beta-blockers [30,42]. Sood and associates have studied the direct effects of catecholamines and cortisol on invasion of ovarian cancer cells using a membrane invasion culture system and the production of key matrix metalloproteinases (MMP), which are involved in tumor cell penetration of the extracellular matrix. Although stress levels of norepinephrine and epinephrine increased the in vitro invasive potential of ovarian cancer cells by $89-198 \%$ and 64-76\% respectively, cortisol did not significantly affect the invasive potential of ovarian cancer cells. Propranolol, the non-specific beta-adrenergic antagonist, completely reversed the norepinephrine-induced increase in invasive potential. Additionally, norepinephrine also enhanced tumor cell expression of MMP-2 and MMP-9, and pharmacologic blockade of MMPs 
abrogated its effects on tumor cell invasive potential. These experimental findings provided evidence that stress hormones can enhance the invasive potential of ovarian cancer cells in vitro [43].

\section{Angiogenesis}

Angiogenesis is a critical process in the growth of most solid tumors beyond 1-2 $\mathrm{mm}$ in diameter, and metastasis requires the recruitment of nearby blood vessels to permeate the tumor [44]. Norepinephrine has been shown to upregulate vascular endothelial growth factor (VEGF) in adipose tissue via the beta-adrenoreceptor/cAMP/protein kinase A (PKA) pathway and in two ovarian cancer cell lines. The upregulation of VEGF by norepinephrine was blocked by a $\beta$-blocker and mimicked by the $\beta$-agonist isoproterenol thereby confirming the functional relevance of the $\beta$-adrenoreceptor in mediating these signals [45,46]. Thaker and colleagues showed that chronic behavioral stress with daily immobilization resulted in higher levels of tissue catecholamines, greater tumor burden, and a more invasive pattern of disease [17]. Microvessel density counts as a measure of angiogenesis were significantly increased in stressed compared to control mice tumor samples. VEGF mRNA and protein levels were also significantly elevated in the stressed tumor samples. A continuous infusion of propranolol abrogated the effects of stress on tumor burden and pattern of disease; therefore, confirming the importance of beta-adrenergic receptors on ovarian cancer cells in an in vivo model. Clinical studies have also shown a correlation between higher levels of social support and lower serum VEGF levels in ovarian cancer patients [47].

Interleukin-6 (IL-6) is another important molecule in tumor progression and angiogenesis [48]. IL-6 has been shown to be secreted by ovarian cancer cells and to enhance tumor cell proliferation and migration in vitro [49,50]. Furthermore, IL-6 is a potent angiogenic cytokine in vivo as evidenced by gelfoam sponge assays, showing a significant increase in microvessel density in the IL-6 impregnated sponges compared to control [48]. Clinically, individuals experiencing chronic stress have been shown to exhibit elevated circulating levels of IL-6 [51]. In ovarian cancer patients, elevated IL-6 is associated with poorer prognosis [52,53]. Lutgendorf and colleagues found that social support was associated with lower levels of IL-6 in the blood and ascites samples of ovarian cancer patients, thereby playing a protective role [54]. Nilsson and associates demonstrated that in ovarian cancer cells, norepinephrine increased IL- 6 mRNA expression by 45 -fold at 6 hours. Significant increases in IL-6 promoter activity were also observed indicating that catecholamines regulate the IL-6 gene at the transcriptional level. The effects of norepinephrine on IL-6 production in ovarian carcinoma cells were found to be mediated through a $\beta$-adrenergic receptor/Src tyrosine kinase axis [55].

Signal transducer and activator of transcription factor-3 (STAT3) is activated by growth factors such as IL-6, promotes angiogenesis by VEGF, and suppresses apoptosis [56]. Due to cytokines such as IL-6 contributing to malignant progression through the activation of STAT3, Landen and colleagues sought to determine if stress hormones have a direct effect on expression and activation of STAT3 in ovarian cancer. They found that both norepinephrine and epinephrine are capable of activating STAT3 with subsequent translocation to the nucleus and DNA binding. STAT3 activation proceeded through $\beta$-adrenergic receptors and protein kinase A in a rapid fashion and was independent of IL- 6 . They concluded that stress-mediated malignant progression may be mediated in part through upregulation of STAT3 leading to the activation of multiple carcinogenic downstream effector pathways [57].

The data pertaining to the effects of glucocorticoids on angiogenesis are limited.

Dexamethasone (a synthetic glucocorticoid) treatment of cancer cells resulted in a 50-60\% downregulation of VEGF mRNA in a rat glioma model, and this effect was dependent on the glucocorticoid receptor function. This inhibitory effect by dexamethasone was markedly 
reduced by hypoxia, which is a known inducer of VEGF [58]. In ovarian cancer cell lines, cortisol had limited stimulating effects at lower doses and inhibitory effects at pharmacologic doses. Since stress causes elevations in both cortisol and catecholamines, co-stimulation experiments in ovarian cancer cell lines were performed. Although priming the cells with cortisol blunted the norepinephrine-induced VEGF production, significant increases in VEGF were still observed [46]. These results demonstrate that catecholamine effects are dominant in the production of angiogenic cytokines.

\section{Cell Survival}

Avoidance of apoptosis is critical to the metastatic cascade. Until recently, most of the data with regard to the effects of stress hormones on tumor cell survival have focused on glucocorticoids. However, Chan and colleagues found that both dopamine and norepinephrine triggered apoptosis via a G protein mediated signaling cascade in neuroblastoma cells but not in lung carcinoma cells [59]. In prostate and breast cancer cell lines, epinephrine (important in acute and chronic stress) reduced the sensitivity of cancer cells to apoptosis through interaction with ADRB2 receptors followed by protein kinase A-dependent BAD phosphorylation [60]. Although large-scale human studies are lacking, a recent epidemiological study showed a decreased incidence of prostate cancer in patients who took beta-blockers regularly thereby implying the importance of the activation of $\beta$-adrenergic receptors on the development of prostate cancer [61].

Glucocorticoids may also activate survival genes that protect cancer cells from the cytotoxic effects of chemotherapy [62,63]. In cervical and lung carcinoma cells, glucocorticoids led to a downregulation of pro-apoptotic elements of death receptor and mitochondrial apoptosis pathways [62]. Similarly, Wu and colleagues found that dexamethasone pretreatment of breast cancer cell lines inhibits chemotherapy-induced apoptosis in a glucocorticoid receptordependent manner and is associated with the transcriptional induction of mitogen-activated protein kinase phosphatase-1 (MKP-1) and serum and glucocorticoid-inducible protein kinase-1 (SGK-1). Specific inhibition of these two proteins with small interfering RNA reversed the anti-apoptotic effects of glucocorticoid treatment [63]. Additionally, glucocorticoids such as cortisol may act synergistically with catecholamines to facilitate cancer proliferation. In lung carcinoma cells, cortisol potentiated the isoproterenol-induced increase in cAMP concentration, increased $\beta$-adrenergic receptor density, and dramatically increased the effects of IL-1 $\alpha$, IL-1 $\beta$, and tumor necrosis factor-alpha [64].

\section{Other stress mediators}

Although epinephrine, norepinephrine, and cortisol are widely considered as the major stress mediators, other hormones such as prolactin, oxytocin, dopamine, and substance $\mathrm{P}$ are affected by stress [40,65-67] \{Table 2$\}$. Prolactin plays a functional role in tumor cell proliferation and promotes survival of breast, prostate, endometrial, and other cancer cells [68-71]. Several epidemiological studies have shown a consistent relationship between prolactin levels and known risk factors for breast cancer such as parity and age at menarche [68]. A significant proportion of breast cancer cell lines express the prolactin receptor and exogenously added prolactin has modest trophic effects on human tumor tissues and cells in vitro [72]. Saez and coworkers demonstrated that exercise-induced stress using a forced swim model enhanced 9,10-dimethyl-1,2benz(a)anthracene mammary tumor growth rate, but not survival time or tumor multiplicity via involvement of catecholamines and prolactin in vivo, and melatonin could offset these effects [73]. However, Thompson and associates showed that in rats with 1methyl-1-nitrosurea induced mammary tumors, which are less sensitive to prolactin, treadmill exercise reduced the mammary cancer incidence rate and tumor multiplicity, thereby underscoring the complexity of neuroendocrine interactions [74]. Additionally, prolactin may also inhibit apoptosis of mammary cancer cells via stimulation of the Akt pathway [75,76]. 
Uniquely, oxytocin inhibits the growth of some epithelial cell (e.g. breast, endometrial) tumors and those of nervous or bone origin, but it has a proliferative effect on trophoblast and other tumors (e.g. small cell lung tumors, Kaposi's sarcoma) [77,78]. The presence of the oxytocin receptor has been described on breast and prostate cancer cells [79-81]. Dopamine is a precursor in the synthesis of catecholamines and a major neurotransmitter in the central and peripheral nervous systems [82]. Chronic stress exposure leads to decreased dopamine release in patients $[83,84]$. Dopamine has been shown to have direct effects on inhibition of cancer cells including breast, melanoma, neuroblastoma, and head and neck cancer cell lines [8589]. The inhibitory effect of dopamine is thought to occur through the dopamine receptors on the tumor cell surface or by auto-oxidation of dopamine creating the generation of reactive oxygen species. Additionally, dopamine may have anti-angiogenic properties and has been shown to inhibit cancer growth in several in vivo experimental models [90,91]. Basu and associates demonstrated that at non-toxic levels, dopamine administration inhibited the angiogenic functions of VEGF via the D2-receptor to induce endocytosis of VEGF receptor 2 on endothelial cells thereby preventing VEGF binding, receptor phosphorylation, and subsequent signaling steps [92]. Teunis and colleagues found that both tumor size and vessel density were lower in rats with a hyperactive dopaminergic system [91]. All these findings suggest a link between dopaminergic activity, angiogenesis, and tumor development. Substance $\mathrm{P}$ is a peptide in the neurokinin family, is located in both the central and peripheral nervous systems, and plays a role in stress reactions, anxiety, and depression [93,94]. Substance $P$ promotes the migration of colon and breast carcinoma cell lines and is a chemoattractant for squamous cell lung cancer [40,41,95].

\section{Summary}

Cancer initiation and progression is a complex process that relies on multiple steps including genetic changes, proliferation, vascularization, invasion, embolization, and evasion of apoptosis. After the primary tumor is established, growth and metastasis can occur depending on interactions with homeostatic mechanisms. In this review, we have focused on the interrelationships between biobehavioral factors and cancer initiation and metastasis. However, our understanding of the underlying mechanisms is still in its infancy and needs to be expanded. These studies may offer new clinical strategies for therapeutic interventions utilizing behavioral and pharmacological approaches that target neuroendocrine pathways that support cancer initiation and metastasis. Already there are some biobehavioral intervention studies that have had promising results in modifying neuroendocrine dysfunction [8]. Betablockers have shown to block the deleterious effects of stress in both in vitro and in vivo models of several carcinomas $[17,21,46]$. Clinically, beta-blockers have been shown to both lower cancer incidence and cancer risk in a cohort of patients $[61,96]$. However, in other studies the cancer risk was neutral [97-99]. Although great strides have occurred in understanding the influence of behavioral factors on cancer initiation and metastasis, further research is required to fully understand the complexity of the mechanisms along with interplay with immune system and to develop meaningful clinical trials. As cancer treatment evolves to have patient-specific therapeutic approaches, the inclusion of pharmacologic and behavioral interventions can be used in combination with conventional therapies to hopefully produce superior outcomes, but further research is warranted.

\section{Acknowledgements}

This research was supported in part by U.S. NIH grants CA110793 and CA109298, The University of Texas M.D. Anderson Cancer Center Spore in Ovarian Cancer (2P50CA083639), and a Program Project Development Grant from the Ovarian Cancer Research Fund, Inc. to A.K.S. 


\section{References}

1. Spiegel D, Giese-Davis J. Depression and cancer: mechanisms and disease progression. Biol Psychiatry 2003;54:269-82. [PubMed: 12893103]

2. Reiche EM, Nunes SO, Morimoto HK. Stress, depression, the immune system, and cancer. Lancet Oncol 2004;5:617-25. [PubMed: 15465465]

3. Dunn, AJ. Psychoneuroimmunology: introduction and general perspectives. In: Leonard, BE.; Miller, K., editors. Stress, the immune system, and psychiatry. Chichester: John Wiley and Sons Ltd; 1996. p. 1-16.

4. Chrousos GP. The hypothalamic-pituitary-adrenal axis and immune-mediated inflammation. N Engl J Med 1995;332:1351-62. [PubMed: 7715646]

5. Sapolsky, R. Why zebras don't get ulcers: A guide to stress, stress-related diseases, and coping. New York: 1994.

6. Weiner, H. Perturbing the Organism: The biology of stressful experience. Chicago: University of Chicago, Press; 1992.

7. Glaser R, Kiecolt-Glaser JK. Stress-induced immune dysfunction: Implications for health. Nature Rev Immunol 2005;5:243-51. [PubMed: 15738954]

8. Antoni MH, Lutgendorf SK, Cole SW, Dhabar FS, Sephton SE, McDonald PG, et al. The influence of bio-behavioural factors on tumour biology: Pathways and mechanisms. Nature Rev Cancer 2006;6:240-8. [PubMed: 16498446]

9. McEwen BS. Sex, stress, and the hippocampus: Allostasis, allostatic load and the aging process. Neurobiol Aging 2002;23:921-39. [PubMed: 12392796]

10. Ben-Eliyahu S, Yirmiya R, Liebeskind JC, Taylor AN, Gale RP. Stress increases metastatic spread of a mammary tumor in rats. Evidence for mediation by the immune system. Brain Behav Immunity 1991;5:193-205.

11. Ben-Eliyahu S, Shakhar G, Page GG, Stefanski V, Shakhar K. Suppression of NK cell activity and of resistance of metastasis by stress: A role for adrenal catecholamines and $\beta$-adrenoceptors. Neuroimmunomodulation 2000;8:154-64. [PubMed: 11124582]

12. Lang K, Entschladen F, Weidt C, Zaenker KS. Tumor immune escape mechanisms: impact of the neuroendocrine system. Cancer Immunol Immunother 2006;55:749-60. [PubMed: 16435128]

13. Ben-Eliyahu S, Page GG, Schleifer SJ. Stress, NK cells, and cancer: Still a promissory note. Brain Behav Immunity 2007;21:881-7.

14. Glaser R, MacCallum RC, Laskowski BF, Malarkey WB, Sheridan JF, Kiecolt-Glaser JK. Evidence for a shift in the Th-1 to Th-2 cytokine response associated with chronic stress and aging. J Gerontol A Biol Sci Med Sci 2001;56:M477-82. [PubMed: 11487599]

15. Ben-Eliyahu S, Page G. In vivo assessment of natural killer cell activity in rats. Prog Neuroendocrine Immunol 1992;5:199-214.

16. Lutgendorf SK, Sood AK, Anderson B, McGinn S, Maiseri H, Dao M, et al. Social support, psychological distress, and natural killer cell activity in ovarian cancer. J Clin Oncol 2005;23:710513. [PubMed: 16192594]

17. Thaker PH, Han LY, Kamat AA, Arevalo JM, Takahashi R, Lu C, et al. Chronic stress promotes tumor growth and angiogenesis in a mouse model of ovarian carcinoma. Nature Med 2006;12:93944. [PubMed: 16862152]

18. Sood AK, Bhatty R, Kamat AA, Landen CN, Han L, Thaker PH, et al. Stress hormone-mediated invasion of ovarian cancer cells. Clin Cancer Res 2006;12:369-75. [PubMed: 16428474]

19. Badino GR, Novelli A, Girardi C, DiCarlo F. Evidence for functional $\beta$-adrenoceptor subtypes in CG-5 breast cancer cell. Pharm Res 1996;33:255-60.

20. Vandewalle B, Revillion F, Lefebvre J. Functional $\beta$-adrenergic receptors in breast cancer cells. J Cancer Res Clin Oncol 1990;116:303-6. [PubMed: 2164516]

21. Palm D, Lang K, Niggemann B, Drell TL, Masur Zaenker KS, et al. The norepinephrine-driven metastasis development of PC-3 human prostate cancer cells in BALB/C nude mice is inhibited by beta-blockers. Int J Cancer 2006;118:2744-9. [PubMed: 16381019]

22. Hanahan D, Weinberg RA. The hallmarks of cancer. Cell 2000;100:57-70. [PubMed: 10647931] 
23. Fidler IJ. The pathogenesis of cancer metastasis: The 'seed and soil" hypothesis revisited. Nat Rev Cancer 2003;3:1-6.

24. Mueller MM, Fusenig NE. Friends or foes-bipolar effects of the tumour stroma in cancer. Nat Rev Cancer 2004;4:839-49. [PubMed: 15516957]

25. Flaxman BA, Harper RA. In vitro analysis of the control of keratinocyte proliferation human epidermis by physiologic and pharmacologic agents. J Invest Dermatol 1975;65:52-9. [PubMed: 239072]

26. Marchetti B, Spinola PG, Pelletier G, Labrie F. A potential role for catecholamines in the development and progression of carcinogen-induced mammary tumors: hormonal control of beta-adrenergic receptors and correlation with tumor growth. J Steroid Biochem Mol Biol 1991;38:307-20. [PubMed: 1848992]

27. Carie AE, Sebti SM. A chemical biology approach identifies a beta-2 adrenergic receptor agonist that causes human tumor regression by blocking the Raf-1/Mek-1/Erk1/2 pathway. Oncogene 2007;26:3777-88. [PubMed: 17260025]

28. Shin VY, Wu WK, Chu KM, Koo MW, Wong HP, Lam EK, et al. Functional role of beta-adrenergic receptors in mitogenic action of nicotine on gastric cancer cells. Toxicol Sci 2006;96:21-9. [PubMed: 17003101]

29. Abramovitch R, Tavor E, Jacob-Hirsch J, Zeira E, Amariglio N, Pappo O, et al. A pivotal role for cyclic AMP responsive element binding protein in tumor progression. Cancer Res 2004;64:133846. [PubMed: 14973073]

30. Lang K, Drell TL 4th, Lindecke A, Niggemann B, Kaltschmidt C, Zaenker KS, et al. Induction of metastatogenic tumor cell type by neurotransmitters and its pharmacological inhibition by established drugs. Int J Cancer 2004;112:231-8. [PubMed: 15352035]

31. Jean D, Bar-Eli M. Regulation of tumor growth and metastasis of human melanoma by the CREB transcription factor family. Mol Cell Biochem 2000;212:19-28. [PubMed: 11108132]

32. Scaparo AC, Sumida DH, Patrao MT, Avellar MC, Visconti MA, Maria de Lauro Castrucci A. Catecholamine effects on human melanoma cells evoked by $\alpha 1$-adrenoceptors. Arch Dermatol Res 2004;296:112-9. [PubMed: 15278367]

33. Pifl C, Zezula J, Spitler A, Kattinger A, Reither H, Caron MG, et al. Antiproliferative action of dopamine and norepinephrine in neuroblastoma cells expressing the human dopamine transporter. Faseb J 2001;15:1607-9. [PubMed: 11427501]

34. Zhao XY, Malloy PJ, Krishnan AV, Swami S, Navone NM, Peehl DM, et al. Glucocorticoids can promote androgen-independent growth of prostate cancer cells through a mutated androgen receptor. Nat Med 2000;6:703-6. [PubMed: 10835690]

35. Simon WE, Albrecht M, Trams G, Dietel M, Holzel F. In vitro growth promotion of human mammary carcinoma cells by steroid hormones, tamoxifen, and prolactin. J Natl Cancer Inst 1984;73:313-21. [PubMed: 6589426]

36. Boudreau N, Bissell MJ. Extracellular matrix signaling: integration of form and function in normal and malignant cells. Curr Opin Cell Biol 1998;10:640-6. [PubMed: 9818175]

37. Hay, E. Biology of the extracellular matrix. New York: Plenum Press; 1991.

38. Rangarajan S, Enserink JM, Kuiperij HB, de Rooij J, Price LS, Schwede F, et al. Cyclic AMP induces integrin-mediated cell adhesion through Epac and Rap 1 upon stimulation of the $\beta_{2}$-adrenergic receptor. J Cell Biol 2003;160:487-93. [PubMed: 12578910]

39. Enserink JM, Price LS, Methi T, Mahic M, Sonnenberg A, Bos JL, et al. The cAMP-Epac-Rap1 pathway regulates cell spreading and cell adhesion to laminin- 5 through the $\alpha 3 \beta 1$ integrin but not the $\alpha 6 \beta 4$ integrin. J Biol Chem 2004;279:44889-96. [PubMed: 15302884]

40. Entschladen F, Drell TL 4th, Lang K, Joseph J, Zaenker KS. Neurotransmitters and chemokines regulate tumor cell migration: potential for a new pharmacological approach to inhibit invasion and metastasis development. Curr Pharm Des 2005;11:403-11. [PubMed: 15723634]

41. Drell TL, Joseph J, Lang K, Niggemann B, Zaenker KS, Entschladen F. Effects of neurotransmitters on the chemokinesis and chemotaxis of MDA-MB-468 breast carcinoma cells. Breast Cancer Res Treat 2003;80:63-70. [PubMed: 12889599]

42. Masur K, Niggemann B, Zaenker KS, Entschladen F. Norepinephrine-induced migration of SW 480 colon carcinoma cells is inhibited by beta-blockers. Cancer Res 2001;61:2866-9. [PubMed: 11306460] 
43. Sood AK, Bhatty R, Kamat AA, Landen CN, Han L, Thaker PH, et al. Stress-hormone-mediated invasion of ovarian cancer cells. Clin Cancer Res 2006;12:369-75. [PubMed: 16428474]

44. Folkman J. What is the evidence that tumors are angiogenesis dependent? J Natl Cancer Inst 1990;82:4-6. [PubMed: 1688381]

45. Fredriksson JM, Lindquist JM, Bronnikov GE, Nedergaard J. Norepinephrine induces vascular endothelial growth factor gene expression in brown adipocytes through a beta-adrenoreceptor/cAMP/ protein kinase A pathway involving Src but independently of Erk 1/2. J Biol Chem 2000;275:1380211. [PubMed: 10788502]

46. Lutgendorf SK, Cole S, Costanzo E, Bradley S, Coffin J, Jabbari S, et al. Stress-related mediators stimulate vascular endothelial growth factor secretion by two ovarian cancer cell lines. Clin Cancer Res 2003;9:4514-21. [PubMed: 14555525]

47. Lutgendorf SK, Johnsen EL, Cooper B, Anderson B, Sorosky JI, Buller RE, et al. Vascular endothelial growth factor and social support in patients with ovarian carcinoma. Cancer 2003;95:808-15. [PubMed: 12209725]

48. Nilsson MB, Langley RR, Fidler IJ. Interleukin-6, secreted by human ovarian carcinoma cells, is a potent proangiogenic cytokine. Cancer Res 2005;65:10794-800. [PubMed: 16322225]

49. Wu S, Rodabaugh K, Martinez-Maza O, Watson JM, Silberstein DS, Boyer CM, et al. Stimulation of ovarian tumor cell proliferation with monocyte products including interleukin-1, interleukin-6, and tumor necrosis factor-alpha. Am J Obstet Gynecol 1992;166:997-1007. [PubMed: 1550178]

50. Obata NH, Tamakoshi K, Shibata K, Kikkawa F, Tomoda Y. Effects of interleukin-6 on in vitro cell attachment, migration, and invasion of human ovarian carcinoma. Anticancer Res 1997;17:337-42. [PubMed: 9066674]

51. Kiecolt-Glaser JK, Preacher KJ, MacCallum RC, Atkinson C, Malarkey WB, Glaser R. Chronic stress and age-related increases in the proinflammatory cytokine IL-6. Proc Natl Acad Sci USA 2003;100:9090-5. [PubMed: 12840146]

52. Tempfer C, Zeisler H, Sliutz G, Haeusler G, Hanzal E, Kainz C. Serum evaluation of interleukin 6 in ovarian cancer patients. Gynecol Oncol 1997;66:27-30. [PubMed: 9234916]

53. Plante M, Rubin SC, Wong GY, Federici MG, Finstad CL, Gastl GA. Interleukin-6 level in serum and ascites as a prognostic factor in patients with epithelial ovarian cancer. Cancer 1994;73:18828. [PubMed: 8137215]

54. Costanzo ES, Lutgendorf SK, Sood AK, Anderson B, Sorosky J, Lubaroff DM. Psychosocial factors and interleukin-6 among women with advanced ovarian cancer. Cancer 2005;104:305-313. [PubMed: 15954082]

55. Nilsson MB, Armaiz-Pena G, Takahashi R, Lin YG, Trevino J, Li Y, et al. Stress hormones regulate IL-6 expression by human ovarian carcinoma cells through a src-dependent mechanism. J Biol Chem. 2007August 23 epub

56. Aggarwal BB, Sethi G, Ahn KS, Sandur SK, Pandey MK, Kunnumakkara AB, et al. Targeting signaltransducer-and-activator-of-transcription-3 for prevention and therapy of cancer: modern target but ancient solution. Ann N Y Acad Sci 2006;1091:151-69. [PubMed: 17341611]

57. Landen CN, Lin YG, Armaiz Pena GN, Das PD, Arevalo JMG, Kamat AA, et al. Neuroendocrine modulation of STAT3 in ovarian cancer. Cancer Res. In press

58. Machein MR, Kullmer J, Ronicke V, Machein U, Krieg M, Damert A, et al. Differential downregulation of vascular endothelial growth factor by dexamethasone in normoxic and hypoxic rat glioma cells. Neuropathol Appl Neurobiol 1999;25:104-12. [PubMed: 10215998]

59. Chan AS, Ng LW, Poon LS, Chan WW, Wong YH. Dopaminergic and adrenergic toxicities on SK$\mathrm{N}-\mathrm{MC}$ human neuroblastoma cells are mediated through $\mathrm{G}$ protein signaling and oxidative stress. Apoptosis 2007;12:167-179. [PubMed: 17136323]

60. Sastry KS, Karpova Y, Prokopovich S, Smith AJ, Essau B, Gersappe A, et al. Epinephrine protects cancer cells from apoptosis via activation of cAMP-dependent protein kinase and BAD phosphorylation. J Biol Chem 2007;282:14094-100. [PubMed: 17353197]

61. Perron L, Bairati I, Harel F, Meyer F. Antihypertensive drug use and the risk of prostate cancer (Canada). Cancer Causes Control 2004;15:535-41. [PubMed: 15280632] 
62. Herr I, Ucur E, Herzer K, Okouoyo S, Ridder R, Krammer PH, et al. Glucocorticoid cotreatment induces apoptosis resistance toward cancer therapy in carcinomas. Cancer Res 2003;63:3112-20. [PubMed: 12810637]

63. Wu W, Chaudhuri S, Brickley DR, Pang D, Karrison T, Conzen SD. Microarray analysis reveals glucocorticoid-regulated survival genes that are associated with inhibition of apoptosis in breast epithelial cells. Cancer Res 2004;64:1757-64. [PubMed: 14996737]

64. Nakane T, Szentendrei T, Stern L, Virmani M, Seely J, Kunos G. Effects of IL-1 and cortisol on betaadrenergic receptors, cell proliferation, and differentiation in cultured human A549 lung tumor cells. J Immunol 1990;145:260-6. [PubMed: 2162889]

65. Dave JR, Anderson SM, Saviolakis GA, Mougey EH, Bauman RA, Kant GJ. Chronic sustained stress increases levels of anterior pituituary prolactin mRNA. Pharmacol Biochem Behav 2000;67:423-31. [PubMed: 11164069]

66. Almeida SA, Petenusci SO, Franci JA, Rosa e Silva AA, Carvalho TL. Chronic immobilization induced stress increases plasma testosterone and delays testicular maturation in pubertal rats. Andrologia 2000;32:7-11. [PubMed: 10702860]

67. Young WS 3, Lightman SL. Chronic stress elevates enkephalin expression in the rat paraventricular and supraoptic nuclei. Brain Res Mol Brain Res 1992;13:111-7. [PubMed: 1349719]

68. Clevenger CV, Furthe PA, Hankinson SE, Schuler LA. The role of prolactin in mammary carcinoma. Endocr Rev 2003;24:1-27. [PubMed: 12588805]

69. Doll F, Pfeilschifter J, Huwiler A. Prolactin upregulates sphingosine kinase-1 expression and activity in the human breast cancer cell line MCF7 and triggers enhanced proliferation and migration. Endocr Relat Cancer 2007;14:325-35. [PubMed: 17639048]

70. Dagvadori A, Collins S, Jomain JB, Abdulghani J, Karras J, Zellweger T, et al. Autocrine prolactin promotes prostate cancer cell growth via Janus kinase-2-signal transducer and activator of transcription-5a/b signaling pathway. Endocrinology 2007;148:3089-101. [PubMed: 17412813]

71. Ben-Jonathan N, Liby K, McFarland M, Zinger M. Prolactin as an autocrine/paracrine growth factor in human cancer. Trends Endocrinol Metab 2002;13:245-50. [PubMed: 12128285]

72. Vonderhaar, BK. Prolactin in human breast cancer development. In: SP, E., editor. Endocrine oncology. Totowa: Humana Press; 2000. p. 101-20.

73. Saez Mdel C, Barriga C, Garcia JJ, Rodriguez AB, Ortega E. Exercise-induced stress enhances mammary tumor growth in rats: beneficial effect of the hormone melatonin. Mol Cell Biochem 2007;294:19-24. [PubMed: 17136443]

74. Thompson HJ, Westerlind KC, Snedden J, Briggs S, Singh M. Exercise intensity dependent inhibition of 1-methyl-1-nitrosourea induced mammary carcinogenesis in female F-344 rats. Carcinogenesis 1995;16:1783-6. [PubMed: 7634404]

75. Chen WY, Ramamoorthy P, Chen N, Sticca R, Wagner TE. A human prolactin antagonist, hPRLG129R, inhibits breast cancer cell proliferation through induction of apoptosis. Clin Cancer Res 1999;5:3583-93. [PubMed: 10589775]

76. Richert, MM.; Decker, K.; Anderson, SM. Mechanisms underlying constitutive activation of Akt in breast cancer cell lines. 83rd Annual Meeting of the Endocrine Society; Denver, CO. 2001. p. 551

77. Pequeux C, Keegan BP, Hagelstein MT, Geenen V, Legros JJ, North WG. Oxytocin-and vasopressininduced growth of human small-cell lung cancer is mediated by the mitogen-activated protein kinase pathway. Endocr Relat Cancer 2004;11:871-5. [PubMed: 15613460]

78. Cassoni P, Marrocco T, Deaglio S, Sapino A, Bussolati G. Biological relevance of oxytocin and oxytocin receptors in cancer cells and primary tumors. Ann Oncol 2001;12:S37-9. [PubMed: 11762350]

79. Taylor AH, Ang VT, Jenkins JS, Silverlight JJ, Coombes RC, Lugmani YA. Interaction of vasopressin and oxytocin with human breast carcinoma cells. Cancer Res 1990;50:7882-6. [PubMed: 2174737]

80. Bussolati G, Cassoni P. Editorial: the oxytocin/oxytocin receptor system-expect the unexpected. Endocrinology 2001;142:1377-9. [PubMed: 11250915]

81. Cassoni P, Marrocco T, Sapino A, Allia E, Bussolati G. Evidence of oxytocin/oxytocin receptor interplay in human prostate gland and carcinomas. Int J Oncol 2004;25:899-904. [PubMed: 15375538] 
82. Velasco M, Luchsinger A. Dopamine: pharmacologic and therapeutic aspects. Am J Ther 1998;5:3743. [PubMed: 10099036]

83. Imperato A, Angelucci L, Casolini P, Zocchi A, Puglisi-Allegra S. Repeated stressful experiences differently affect limbic dopamine release during and following stress. Brain Res 1992;577:194-9. [PubMed: 1606494]

84. Isovich E, Mijnster MJ, Flugge G, Fuchs E. Chronic psychosocial stress reduces the density of dopamine transporters. Eur J Neurosci 2000;12:1071-8. [PubMed: 10762338]

85. Johnson DE, Ochieng J, Evans SL. The growth inhibitory properties of a dopamine agonist (SKF38393) on MCF-7 cells. Anticancer Drugs 1995;6:471-4. [PubMed: 7670147]

86. Lai CT, Yu PH. Dopamine- and L-beta-3,4-dihydroxyphenylalanine hydrochloride (L-Dopa)-induced cytotoxicity towards catecholaminergic neuroblastoma SH-SY5Y cells. Effects of oxidative stress and antioxidative factors. Biochem Pharmacol 1997;53:363-72. [PubMed: 9065740]

87. Wick MM. Levodopa and dopamine analogs as DNA polymerase inhibitors and antitumor agents in human melanoma. Cancer Res 1980;40:1414-8. [PubMed: 6768447]

88. Wick MM, Mui A. Synthesis and biologic evaluation of the dopamine analog $\mathrm{N}$-acetyldopamine in experimental leukemia in mice. J Natl Cancer Inst 1981;66:351-4. [PubMed: 6935484]

89. Fitzgerald GB, Wick MM. Comparison of inhibitory effects of hydroxyurea, 5-fluorodeoxyuridine, 3,4-dihydroxybenzylamine, and methotrexate on human squamous cell carcinoma. J Invest Dermatol 1987;88:66-70. [PubMed: 2947954]

90. Chakroborty D, Sarkar C, Mitra RB, Banerjee S, Dasgupta PS, Basu S. Depleted dopamine in gastri cancer tissues: dopamine treatment retards growth of gastric cancer by inhibiting angiogenesis. Clin Cancer Res 2004;10:4349-56. [PubMed: 15240521]

91. Teunis MA, Kavelaars A, Voest E, Bakker JM, Ellenbroek BA, Cools AR, et al. Reduced tumor growth, experimental metastasis formation, and angiogenesis in rates with a hyperreactive dopaminergic system. FASEB J 2002;16:1465-7. [PubMed: 12205050]

92. Basu S, Nagy JA, Pal S, Vasile E, Eckelhoefer IA, Bliss VS, et al. The neurotransmitter dopamine inhibits angiogenesis induced by vascular permeability factor/vascular endothelial growth factor. Nature Med 2001;7:569-74. [PubMed: 11329058]

93. Mantyh PW. Neurobiology of substance P and the NK1 receptor. J Clin Psychiatry 2002;63:6-10. [PubMed: 12562137]

94. Kramer MS, Cutler N, Feighner J, Shrivastava R, Carman J, Sramek JJ, et al. Distinct mechanism for antidepressant activity by blockade of central substance P receptors. Science 1998;281:1640-5. [PubMed: 9733503]

95. Ruff M, Schiffmann E, Terranova V, Pert CB. Neuropeptides are chemoattractants for human tumor cells and monocytes: a possible mechanism for metastasis. Clin Immunol Immunopathol 1985;37:387-96. [PubMed: 2414046]

96. Algazi M, Plu-Bureau G, Flahault A, Dondon MG, Le MG. Could treatments with beta-blockers be associated with a reduction in cancer risk? Rev Epidemiol Sante Publique 2004;52:53-65. [PubMed: 15107693]

97. Li CI, Malone KE, Weiss NS, Boudreau DM, Cushing-Haugen KL, Daling JR. Relation between use of antihypertensive medications and risk of breast carcinoma among women ages 65-79 years. Cancer 2003;98:1504-13. [PubMed: 14508839]

98. Meier CR, Derby LE, Jick SS, Jick H. Angiotensin-converting enzyme inhibitors, calcium channel blockers, and breast cancer. Arch Intern Med 2000;160:349-53. [PubMed: 10668837]

99. Rosenberg L, Rao RS, Palmer JR, Strom BL, Stolley PD, Zauber AG, et al. Calcium channel blockers and the risk of cancer. JAMA 1998;279:1000-4. [PubMed: 9533498] 


\section{Table 1}

Steps involved in metastasis

1 Proliferation and growth of primary tumor

2 Detachment or shedding of cells from primary tumor into circulation

3 Survival of cancer cells in circulation

4 Transport of cancer cells to new organs with subsequent arrest

5 Extravasation into surrounding tissues

6 Angiogenesis and growth of metastatic tumor 


\section{Table 2}

Neurotransmitters with known function in Tumor Proliferation and Metastasis

\begin{tabular}{|l|l|l|}
\hline Neurotransmitter & Tumor Cell Tvpe & Receptor \\
\hline Norepinephrine & Breast, ovarian, prostate, colon & $\beta 2$-adrenoreceptor [17,30,42,46,53,54,58,59] \\
\hline Epinephrine & Ovarian & $\beta 2$-adrenoreceptor [17,54] \\
\hline Cortisol & Prostate, breast & Glucocorticoid receptor [34,35,5661,62] \\
\hline Prolactin & Breast. prostate, endometrial & Prolactin receptor $[66-70]$ \\
\hline Oxvtocin & Small cell lung, Kaposi's sarcoma & Oxvtocin receptor [74,75] \\
\hline Dopamine & Breast, melanoma, neuroblastoma, head \& neck & D2-receptor [41,82-86] \\
\hline Substance P & Breast, colon, lung & Neurokinin-1 receptor [40,41,92] \\
\cline { 2 - 3 } & &
\end{tabular}

This list is meant to be illustrative and not comprehensive with regard to tumor cell types and references. 